\title{
MUSIIKKI TEEMANA SUOMEN MYÖHÄISKESKIAJAN KALKKIMAALAUKSISSA
}

Myöhäiskeskiajan kalkkimaalaukset $\cdot$ musiikki-ikonologia $\cdot$ metodit $・$ 1400-1500 -luvut - Neitsyt Maria - Ahvenanmaa - Taivassalo, Hattula - harppu • säkkipilli • Piru • hyvä ja paha

Eri taiteenalojen välisten suhteiden selvittäminen on varsin haastava ja vaikea tehtävä, joka edellyttää perehtyneisyyttä usean eri tieteenalan metodiikkaan ja tutkimusaineistoon. Musiikin ja kuvataiteiden välisiă suhteita on selvitetty jo renessanssin aikana taiteilijoiden jäljentäessä antiikin taidetta ja niihin kuvattuja soittimia, mutta erityinen musiikki-ikonologiaksi tai musiikki-ikonografiaksi nimitetty tutkimussuunta on varsin nuori, tällä vuosisadalla kehittynyt.

Ensimmäiset musiikin ja kuvataiteiden suhteita pohtivat tutkijat olivat saksalaisia musiikinhistoriaan ja kulttuurihistoriaan suuntautuneita sekä etnomusikologeja että perinteisiä musiikkitieteilijöită. Erich von Hornbostel esimerkiksi on pohtinut eri taiteiden vălisiä suhteita sellaisina kuin ne ilmenevăt alkuperäiskansojen taiteissa, Curt Sachs on käyttänyt soitinhistorioissaan varsin paljon taideteoksissa kuvattuja soittimia sekä kuvituksena että todistusaineistona, ja samoin on tehty Heinrich Besselerin, Max Schneiderin ja Werner Bachmannin toimittamassa moniosaisessa sarjassa Musikgeschichte in Bildern (1961-). ${ }^{1}$ Vuodesta 1971 on New Yorkin yliopistossa toiminut musiikki-ikonografian tutkimuskeskus. ${ }^{2}$ Hyvän kuvan tutkimussuunnan mahdollisuuksista saa perehtymällä esimerkiksi Emanuel Winternitzin (1967) esseekokoelmaan Musical Instruments and their Symbolism in Western Art.

Musiikki-ikonologian - kuten yleensä monitieteisten tutkimusalojen suurimpana ongelmana lienee metodiikka. On tunnettava varsin monen tieteenalan tutkimusmenetelmiä, erityisesti taidehistorian ja musiikinhistorian, sekä sovitettava täysin erilaiset tutkimusperinteet jollain tavoin yhteen molempia tieteenaloja tyydyttävällä tavalla. Musiikki-ikonologian alalta puuttuukin toistaiseksi metodisesti painottunut tutkimus lähes kokonaan. Edellytykset oman metodiikan kehittämiselle ovat kuitenkin jo olemassa, sillä perustyö, tutkimusaineiston kokoaminen on varsin pitkällä ja kansainvälisten periaatteiden 
mukaan organisoituja musiikkiaiheisten taideteosten kuva-arkistoja on eri puolilla maailmaa.

Tässä artikkelissa pyrin selvittämään muutaman esimerkin avulla mită musiikki, tai oikeammin musiikin merkit kuten soittimet, nuotit, laulajat, tanssijat ja soittajat ilmaisevat Suomen myöhåiskeskiajan kalkkimaalauksissa.

\section{Keskiajan kuvataide}

Keskiajan kirkkomaalausten funktiota ei ole täydellă varmuudella pystytty selvittämään. Suuri osa maalauksista on kristillisen opin kuvituksia, mutta olivatko ne ensisijaisesti tarkoitettu lukutaidottomien opetukseksi, ei ole varmaa. Tosin kirkkoisä Gregorius Suuri (+604) nimitti kirkkomaalauksia Biblia pauperumiksi, köyhien Raamatuksi, mutta maalauksiin kuuluu myős paljon kuva-aiheita ja yksittäisiă piirteită, joita ei voi ymmärtäă kuin kristinoppiin hyvin perehtynyt henkilö. Myöskään kuvien koristeellinen ja esteettinen sisăltö ei ole ollut toisarvoinen, joskin tärkeintă on ollut kuvan sanoma. Sanan ensiarvoisuutta kristillisessä perinteessä kuvastaa jo Raamatun luomiskertomus, ettå koko maailma syntyi Jumalan sanan avulla, ja kirkkoisă Gregorius Suuri nimitti kuvataidetta sanan korvikkeeksi. (Kunstle 1979, 67; Nilsen 1986, 247 248).

Keskiajan katolinen kulttuuri on ollut melko yhtenäistă koko Euroopassa, yhteisen oppirakennelman sekä yhteisen latinan kielen ansiosta. Myöskin kirkolliset kuva-aiheet olivat samantapaisia, toisinaan hyvinkin kaavoittuneita. Taiteessa ei siis pyritty yksilöllisyyteen eikå jäljittelemään todellisuutta.

Suomen keskiajan kuvataide koostuu pääosin kivikirkkojen seinien ja holvien myöhäiskeskiaikaisista maalauksista, 1400-luvulta ja 1500-luvun alusta. Maalausten tekijät ovat yleensä tuntemattomia, mutta tyylillisesti suuri osa kirkkomaalauksista liittyy Upplannin ja Tukholman seudun maalauksiin. Kaksi nimeltä tunnettua maalaria, Peter Henriksson ja Lars Snickare, ovat Ruotsista tulleita ja monien muiden kirkkojen maalarit ovat epäilemättă saaneet ainakin oppinsa Ruotsissa. Eräät taidehistorioitsijat ovat havainneet myös balttilaisia vaikutteita kirkkomaalauksissa. (Nilsen 1986, 6-16).

\section{Keskiajan musiikkinäkemys}

Keskiajan musiikinteoreettisten kirjoitusten perusteella musiikki ymmärrettiin hyvin laajasti, ei ainoastaan soivana äänenä. Musica mundana merkitsi koko maailmankaikkeuden sointia ja värähtelyä, enkelten laulua Jumalan kunniaksi ja harmonisia lukusuhteita, jotka ylläpitivät sfäärien liikettä. Musica humana oli ihmismielen harmoniaa, jossa vallitsivat samat lukusuhteet kuin taivaan värähtelyssä ja liturgisessa laulussa. Vain kolmas kategoria, musica instrumentalis tarkoitti soivaa musiikkia, niin laulua kuin soittoa. Musiikki oli siis paitsi 
esteettinen nautinto myös syvällistä mietiskelyä, ihmisen pyrkimystä yhtyä taivaalliseen ylistyslauluun. (Ling 1983, 94-95).

Taivaallisen musiikin vastakohtana oli helvetin valitus ja itku. Năitä äăniä ei oikeastaan pidetty musiikkina muuta kuin siinä mielessä, ettă ne olivat yritystä laulaa. Uskottiin pirun pyrkivän kaikessa jäljittelemään Jumalaa, kuitenkaan koskaan onnistumatta. Esimerkiksi legendassa Neitsyt Marian kuolemasta kuvaillaan kuinka enkelien laulaessa ylistyslaulua Jumalalle tähän lauluun tahtomattaan yhtyivät myös kadotetut ja koko helvetin väki omalla tavallaan, ulisten ja vaikertaen. (Hammerstein 1974, 18).

Ihmisten musiikin uskottiin olevan mahdollista taikoa joko hyväksi tai pahaksi, se palveli joko hyvä tai pahaa. Kiertävät muusikot ja ilveilijät olivat kirkonmiesten mukaan pirun apulaisia, he johdattivat ihmisiä syntiin. Eräässä saksalaisessa 1400-luvun saarnassa mainitaan, ettă tanssiväki, tanssipaikka ja muusikot ovat saatanallisia ja he yhdessä muodostavat antikirkon (Hammerstein 1974, 51). Ruotsi-Suomen valtakunnassa muusikkoa sai 1200 -luvulla rankaisematta lyödä ja 1400-luvun lakien mukaan lahjoja tuli antaa "... klostareihin eli kirkoihin ia ei leikaritten ia häpiällisten wierasten iotka iumala pilkavat". (Haavio 1932, 12-17).

\section{Taivaan musiikki}

Ahvenanmaan saaristoon kuuluvalla Kumlingen saarella on pieni yksilaivainen kirkko, jonka seinät ja holvit on kauttaaltaan koristettu maalauksin. Maalaukset on tehty 1400-1500 -lukujen vaihteessa, niiden tekijä on tuntematon. Tyylillisiä samankaltaisuuksia on sekä Upplannin että Manner-Suomen kirkkomaalauksissa, mutta Kumlingen maalauksia ei voi määrittää mihinkään tiettyyn koulukuntaan kuuluviksi.

Lähinnä pääalttaria olevaan holviin on kuvattu kaksi soittavaa enkeliä, samaan holviin on kuvattu myös naispyhimyksiä sekä enkeli kirjoitusnauhan kanssa. Enkelten soittimina ovat harppu ja tuntematon jousisoitin. Jousisoitin muistuttaa luuttua, mutta sitä soitetaan jousella. Tällaisesta soittimesta ei ole säilynyt kirjallisia dokumentteja; ei myöskään ole tavattu sellaisia luuttuja, joita olisi mahdollista soittaa jousella, ts. luuttuja, joihin olisi asennettu talla. Sen sijaan kuvataiteissa on toisinaan kuvattu luutun näköinen jousisoitin, ainakin Rauman ja Upplannin kalkkimaalauksissa, italialaisessa Quattrocenton maalauksessa sekä saksalaisessa painetussa kirjassa Das Narrenschiff. 3

Toisen enkelin soittimeksi maalattu harppu on melko isokokoinen ja kehyksen kaareva osa on kulmikas. Juuri tällä tavoin kuvattua harppua en ole tavannut muualla kuvataiteissa, lähes nelikulmaista kehysmuotoa ei ole myöskään säilyneissä harpuissa. Harppu on ollut myöhäiskeskiajalla tavallinen hovien soitin, samoin kuvataiteissa se on usein kuvattu enkelten sekä kuningas Daavidin soittimeksi.

Raamatussa kuvataan enkelten ja Jumalan ääntä useasti pelottavaksi ja voimakkaaksi, kuin ukkosen jylinäksi, tuulen suhinaksi tai pasuunan ääneksi, mutta lähellä Jumalaa taivaalliset äänet muuttuvat suloisiksi ja kauniiksi. 
Kuvat 1 ja 2. Tuntemattoman taiteilijan tekemä holvimaalaus Kumlingen kirkosta. Vierekkäisiin holvivaippoihin on kuvattu kaksi soittavaa enkeliä. Vasemmanpuoleinen enkeli soittaa harppua, oikeanpuoleinen tuntematonta kielisoitinta. Maalaus on tehty joko 1400 -luvun lopussa tai 1500 -luvun alussa.

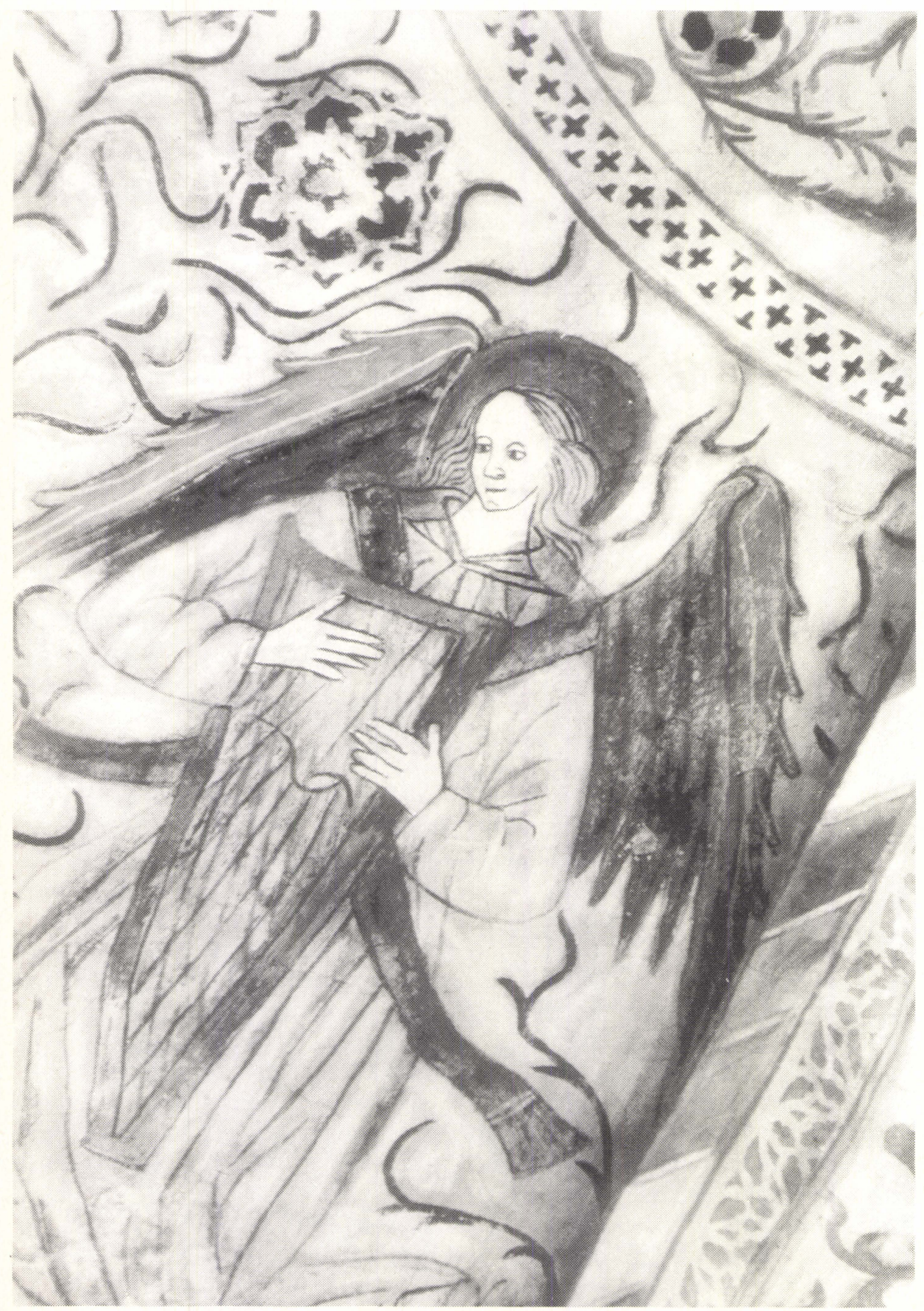




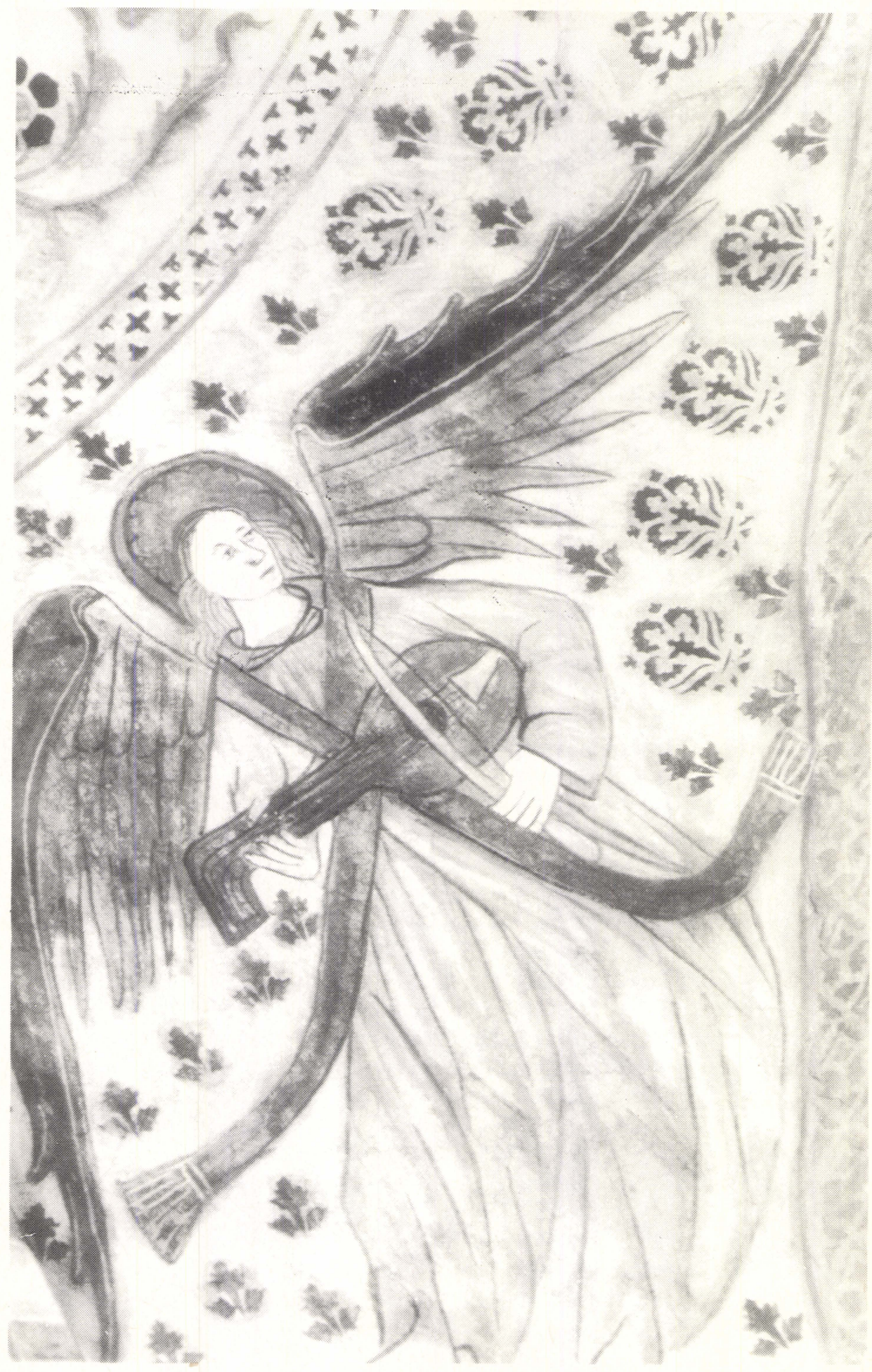


Esimerkiksi kun Herra ilmestyi Elisalle, oli aluksi myrsky ja maanjäristys. Maanjäristyksen jälkeen tuli tulta, "mutta ei Herra ollut tulessa. Tulen jälkeen tuli hiljainen tuulen hyminä ja katso, hänelle puhui Herran ääni." (IKun.19:1113).

Huolimatta siitä, ettei Raamatussa, apokryfeissä eikä latinankielisissä legendoissa mainita enkelten soittavan muita kuin pasuunoita, kuvattiin kirkkomaalauksissa 1300- luvulta lähtien yleisesti kielisoittimia soittavia enkeleitä. Erityisen tavallisia enkelimuusikot ovat esimerkiksi Marian kuolemaa, taivaaseennousua ja kruunausta esittävissä maalauksissa. Legenda Aurea, keskiajan levinnein legendakokoelma 1200-luvun lopulta, kuvailee kuinka Marian kuollessa enkelit laulavat suloisesti (dulcia cantica frequentantur). Reinhold Hammerstein onkin tulkinnut kielisoittimia soittavat enkelit taivaallisen ylistyslaulun ja sen suloisuuden vertauskuvaksi. (Hammerstein 1962, 93-94, 220-222).

Raamatun näkemys taivaan musiikista kuvastuu myös Kumlingen kalkkimaalauksissa. Lähinnä ulko-ovea olevaan läntisimpään holviin on kuvattu kaksi pasuunaa puhaltavaa enkeliă; enkelin äăni on kuin pasuunan pauhu. Itäisimmässä holvissa, lähellä kirkon pyhintä paikkaa, alttaria - ja siis lähinnä Jumalaa - enkelten ääni kuitenkin muuttuu hiljaiseksi ja kauniiksi, kuin kielisoittimien soitoksi.

\section{Musiikki houkuttelee syntiin}

Taivassalossa on kolmilaivainen keskiaikainen kivikirkko, jonka maalauskoristelu on vain osittain säilynyt. Maalausten arviointia vaikeuttaa Emil Nervanderin 1800-luvun lopulla karkeasti päällemaalaten suorittama restaurointi. Osa maalauksista on jopa siirretty kirkossa toiseen paikkaan. Maalaukset on tehnyt Peter Henrikssonin koulukunta 1470-luvulla.

Kirkon länsipäädyssä, etelälaivan eteläseinällä on alkuperäisellä paikalla maalaus, joka esittä kahta polvistuvaa henkilöa. Punapukuinen mies soittaa yhdellä bordunapillillä varustettua săkkipilliä, ja valkopukuinen nainen pităä käsissään kahta esinettä, mielestäni oluttuoppia ja leipäă, kuten myös Emil Nervander ja Timo Leisiö arvelevat. (Nervander 1900, 68; Leisiö 1983, 181).

Useat taidehistorioitsijat ovat kuitenkin tulkinneet esineet soittimeksi, tosin ilman perusteluja. L. Wennervirran mukaan naisella olisi säkkipilli (Suomen keskiaikainen maalaus 1937, 105), Tove Riska käyttää maalauksesta nimeä "Kaksi säkkipillinpuhaltajaa" $(1959,74)$ ja Anne Nilsen nimittää esineitä tuntemattomaksi soittimeksi $(1986,222)$. Uusimman Suomen historian yleisteoksen kuvatekstissä mainitaan jopa: "tässä kaksi säkkipillinsoittajaa, joista naisella on borduna eli bassopilli" (Suomen historia 2, 1985, 198).

Maalausta säkkipillinsoittajasta on useasti pidetty maallisena aiheena, kuvauksena arkipäivän elämästä (esim. Wennervirta 1930, 123). Nähdäkseni maalaus on kuitenkin ennen kaikkea vertauskuvallinen esitys synnistä ja sen palkasta. Kiertävä muusikko ja hänen soittimensa, puupuhaltimet, rummut ja säkkipilli, liitettiin usein paheisiin ja synnilliseen elämäăn, ja kirjallisuudessa 
Kuva 3. Peter Henrikssonin koulukunnan seinämaalaus Taivassalon kirkosta 1470 luvulta. Maalaus esittää säkkipillinsoittajaa, jolle nainen tarjoaa luultavasti olutta ja leipää. Alapuolelle on kuvattu ihmisen ja kalan sekasikiö.

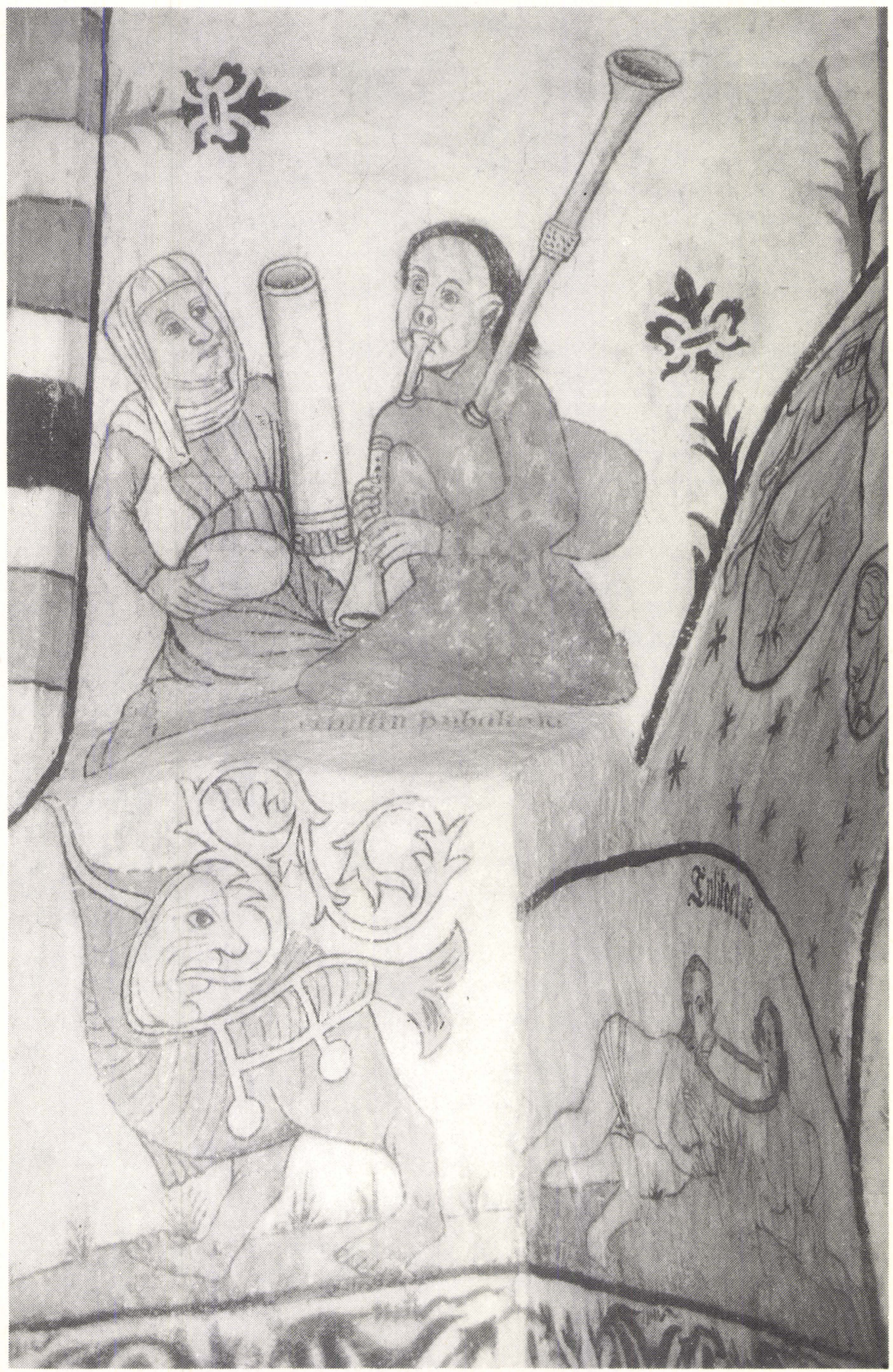


varoitetaan monesti tanssimusiikin haitallisesta vaikutuksesta ihmisiin. Esimerkiksi saksalaisessa 1400-luvun lopun saarnassa sanotaan, että ne jotka nauttivat maallisista, synnillisistä lauluista ja fistula-musiikista huutavat sitä kauheammin helvetissä. (Hammerstein 1974, 28-29).

Säkkipilli oli keskiajan lopulla vähäarvoinen, leimallisesti kiertävien ammattimuusikoiden sekä talonpoikien soitin. Kuvataiteissa se on useasti pirun soittimena ja se kuului kirkonoppineiden kiroamiin fistula-soittimiin. (Mahling 1976, 63-67). Koska Suomessa säkkipilli ei ole koskaan ollut talonpoikaisessa käytössä on mm. tämän maalauksen perusteella päätelty meilläkin kierrelleen ulkomaalaisia ammattimuusikoita (Leisiö 1983, 181-183).

Soittajan alhaista asemaa osoittamaan on maalauksessa musikantin nenä kuvattu sian kärsän kaltaiseksi. Jo Raamatussa eläimet jaotellaan puhtaisiin ja epäpuhtaisiin, ja sama merkitys on eläinten osilla. Sika on saastainen eikä sen lihaa saa syödä, ja Jeesus puhuu vuorisaarnassa: "Älkää antako pyhää koirille, älkääkä heittäkö helmiänne sikojen eteen, etteivät ne tallaisi niitä jalkoihinsa ja kääntyisi ja repisi teitä." (esim. 3Moos.11:7; Matt.7:6). Myös kirkkoisät pitivät sikaa synnin merkkinä ja Physiologus, varhaiskristillinen luonnontieteen kirja, nimitti karjua itse piruksi.

Rohkean restauraation vuoksi sellainen yksityiskohta kuin soittajan hehkuvan punainen puku ei välttämättä ole alkuperäinen. On kuitenkin mahdollista, että tähän korostettuun, suurena pintana maalattuun väriin sisältyisi symboliikkaa. Punainen merkitsi helvetin hehkua ja syntiä, ja Ilmestyskirjan portto, joka johti maan asukkaat syntiin, oli pukeutunut punaisiin vaatteisiin; samoin peto, jolla hän ratsasti oli punainen (Ilm. 17:3-4).

Keskiajan kuvasymboliikka on kuitenkin ollut moniselitteistä, ja vertauskuvilla sekä symboleilla oli useita täysin vastakkaisiakin merkityksiä. Niinpä sika, erityisesti karju, oli myös sotilaallisen rohkeuden ja kuolemaa pelkäämättömyyden symboli, ja sellaisena tavallinen vakuunaeläin. Punainen väri puolestaan merkitsi myös taivaan loistoa tai rakkautta. Asiayhteys ratkaisi mitä merkitystä kulloinkin oli tavoiteltu.

Taivassalon kirkossa "Nainen ja säkkipillinsoittaja" - maalauksen alapuolelle on kuvattu sekasikiö, kalan ja ihmisen sekamuoto, jonka valjaissa on kulkusia. Tällaisia sekasikiöitä pidettiin saatanallisina, koska ne olivat tavallisia pakanakulttuurien taiteissa kuten kentaurit tai sfinksit. Raamatun mainitsemat sekaolennot, serafit, kerubit ja tetramorfit sen sijaan olivat pyhiä. (Hammerstein 1974, 80-82). Sekasikiö Taivassalon maalauksessa varmistaa, ettei yläpuolella olevia henkilöitä tulkita väärin; soittaja houkuttelee naista syntiin, jonka palkkana on kadotus. ${ }^{4}$

\section{Ihmisten musiikki jumalan kunniaksi}

Hattulan kirkon seinä- ja holvimaalaukset ovat varsin hyvin säilyneet ja kolmilaivainen kirkko on kauttaltaan maalausten koristama. Maalarit ovat tuntemattomia, mutta koska läheisen Lohjan kirkon maalaukset ovat saman mestarin ja hänen oppilaidensa työtä, käytetään tekijöistä nimeä Hattula-Lohja -kou- 
Kuva 4. Hattula-Lohja koulukunnan holvimaalaus Hattulan kirkossa 1510-22 luvuilta. Maalauksessa enkeli ilmoittaa Joakimille Neitsyt Marian syntymästä. Joakimin jalkojen juureen on kuvattu suurta sarvitorvea soittava paimen. (Kuva: Museovirasto).

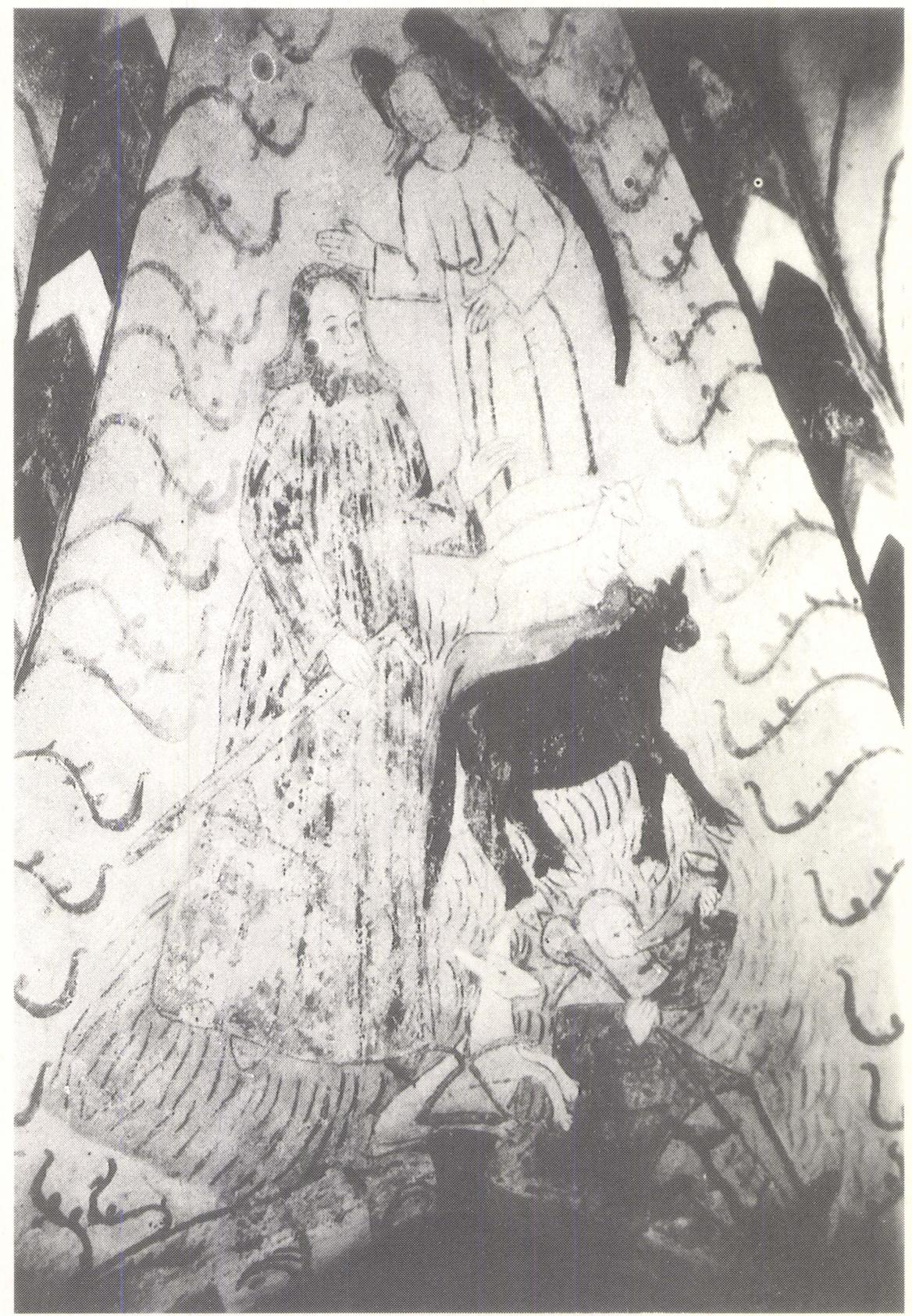


lukunta. Molemmat kirkot on maalattu vuosien 1510-22 välisen aikana. Tyylillisiă yhtälăisyyksiă on Upplannin kirkkomaalauksissa, mutta osa Hattulan ja Lohjan kirkkojen kuva-aiheista on Ruotsissa tuntemattomia.

Hattulan kirkon etelälaivan itäisimmässä holvissa, lähellä alttaria, on maalaus Joakimin ilmestyksestä. Aihe perustuu Jaakobin apokryfievankeliumin tarinaan Neitsyt Marian vanhemmista, Joakimista ja Annasta. He olivat hurskas ja varakas pariskunta, jolla ei ollut lapsia. Kerran kun Joakim toi temppeliin uhrilahjansa, hänet käännytettiin pois, koska hänellä ei ollut perillisiä. Silloin Joakim tuli surulliseksi ja leiriytyi erämaahan paastoamaan ja rukoilemaan. 40 päivän kuluttua hänelle ilmestyi Jumalan enkeli kertoen Annan tulevan raskaaksi. Silloin Joakim käski paimentensa tuoda hänelle 10 virheetöntä karitsaa sekä paljon muita eläimiä kiitosuhriksi Jumalalle ja hän palasi iloiten vaimonsa luo. (Apokryfiset evankeliumit 1979, 13-14).

Hattulan holvimaalauksessa ylimpänä on enkeli, hänen alapuolellaan Joakim ja Joakimin jaloissa karjaa sekä istuva, huppupäinen paimen, joka puhaltaa suureen sarvitorveen. Tämä kuva-aihe on varsin tavallinen keskiajan taiteissa ja paimenelle kuvattiin usein soitin, vaikkei tarinassa mainita paimenen soittavan.

"Joakimin ilmestys" on Suomessa kuvattu myös Lohjan kirkkoon, joskin maalaus on osittain tuhoutunut. Näkyvissä on Joakim ja paimen karjoineen. Paimen soittaa suoraa, kartionmuotoista trumpettia. Myös Ruotsin ja Tanskan kirkkomaalauksissa aihe on tavallinen.

Dorothy Falcon-Mollerin mukaan paimenten soitto on ilon ilmausta ja soitin heidän ammattikuntansa tunnus. Soittaessaan he yhtyvät taivaalliseen ylistyslauluun enkelten kanssa ja ilmaisevat ilonsa enkelin sanomasta. Mielestäni tulkinta vaikuttaa oikealta ja myös samantapaisessa jouluevankeliumin kuvituksessa "Enkelten ilmestyminen paimenille" paimenet useasti soittavat. Vaikuttaa myös siltä, että soitin on todella ammattikunnan tunnus. Vastaavissa kuva-aiheissa Skandinaviassa paimenilla on useimmiten säkkipilli, siellä talonpoikaissoittimena käytetty, mutta Suomen maalauksissa paimenten soitin on sarvitorvi tai puutrumpetti, vaikka kuva-aiheet muutoin ovat samantapaisia. (Falcon-Moller 1980, 216).

\section{Musiikki hyvän ja pahan palveluksessa}

Eräs keskiaikaisen ajattelutavan kulmakivistä oli maailman kokeminen hyvän ja pahan välisen taisteluna, jossa taistelun kohteena oli ihmissielu. Tämä taistelu oli käynnissä kaikkialla, niin ihmiskunnassa kuin eläinkunnassa ja ulottui myös musiikin alueelle. Suomen keskiajan kirkkomaalauksissa voi nähdä soiton, laulun ja tanssin olevan osa niin taivaan ja helvetin kuin maanpäällistä elämää. Kuva-aiheiden laulun, soiton ja tanssin analysointi ja musiikin merkityksen selvittäminen näyttää monesti olevan ratkaisevaa koko kuva-aiheen ymmärtämiseksi.

Kaikkein tavallisimmin Suomen kirkkomaalauksissa kuvataan taivaan musiikkia ja erityisesti enkelimuusikkoja, mutta toisinaan myös piru tai kuolema ovat soittajina ja tanssijoina. Ihmisen esittämä musiikki on useasti maalauksissa 
selvästi tulkittavissa joko Jumalan ylistykseksi tai houkuttelemassa syntiin, ratkaisevaa on kuva-aiheen sisältő sekä erityiset synnin merkit. Piruun ja pakanallisuuteen viittaavat maalauksissa esimerkiksi kaviojalka, sian kärsä tai sekasikiö.

Aina eivät kirkkomaalausten soittajat, laulajat tai tanssijat kuitenkaan ole yksiselitteisesti asetettavissa hyvän tai pahan kategoriaan tai selitettävissä kristillisen opin avulla. Suomessa erityisesti nk. primitiivisen tyylin kalkkimaalauksissa on yksittäisiä, mihinkään tunnettuun aiheeseen kuulumattomia trumpetinsoittajia, joita on vaikea tulkita silloin kun heillä ei ole selviä pyhimyksen, enkelin tai pirun tunnusmerkkejä.

Koska tietomme keskiajan soitinmusiikista Suomessa ovat erittäin vähäiset olisi kiinnostavaa selvittää, missä määrin maalauksiin kuvattuja soittimia voi pitää musiikinhistoriallisina todisteina. Kuten edelläolevasta ilmenee, keskiajan kuvataiteessa näennäiseen arkipäivän elämän kuvaukseenkin sisältyy paljon symboliikkaa. Musiikki- ikonologi Howard Mayer Brown huomauttaa artikkelissaan "Iconography of music", että musiikin esityskäytäntöjä tutkittaessa "only scenes depicting real life can be said to illustrate reality" $(1980,15)$. Näin ajatellen keskiajan kirkkomaalausten musiikkiaiheita ei voi käyttää musiikinhistorian todistusaineistona - ainakaan ilman perusteellista lähdekriittistä selvitystä, vertailua vastaaviin kuva-aiheisiin muualla sekä kaikkiin mahdollisiin musiikinhistorian tietoihin.

\section{Viitteet}

1. Hornbostelin ajatuksia kaikkien aistien alkuperäisestä yhteenkuuluvuudesta ovat siteeranneet ja kommentoineet $\mathrm{mm}$. Alan Merriam teoksessa The Anthropology of Music (1964, 99-100) sekä Kenneth Gourlay artikkelissa The Role of Ethnomusicologist in the creation of the Musical Future (Musiikin Suunta 1/1986). Curt Sachsin soitinhistorian tutkimuksia ovat $\mathrm{mm}$. Real-Lexikon der Musikinstrumente (1913), Handbuch der Musikinstrumentenkunde (1930 2.p.) sekä The History of Musical Instruments (1940).

2. Research Center for Musical Iconography (RCMI), The City University of New York, 33 West 42 Street, New York, N.Y. 10036. Tutkimuskeskus julkaisee kahdesti vuodessa ilmestyvää lehteä RIdIM/RCMI Newsletter ja sen yhteydessä toimii musiikkiaiheisten kuvien arkisto, Repertoire International d'Iconographie Musicale (RIdIM).

3. Valokuva Rauman kalkkimaalauksesta "Neitsyt Marian kruunaus" on julkaistu teoksessa Istvan Racz, Suomen keskiajan taideaarteita (1960, kuva 120), Upplannin maakunnan Älvkarlebyn kirkon seinämaalauksesta "Anna itse kolmantena" on valokuva Leif Jonssonin artikkelissa Musik mellan himmel och helvete (Katolsk årsbok 1978, 80) ja Sebastian Brantin kirjan Das Narrenschiff (1497) puupiirros katusoittajista on julkaistu ainakin Walter Salmenin ja Heinrich Schwabin teoksessa Musikgeschichte Schleswig- Holsteins (1971, Tafel 23.1).

4. Suullisen tiedon mukaan Tanskassa on parissa kalkkimaalauksessa esitetty sama aihe naisesta ja säkkipillinsoittajasta (Kjell Ivarsson 1985, Lisbeth Lund 1986). 


\section{Lähteet}

\section{Anonyymi}

1979 (1978) Apokryfiset evankeliumit. Suomentanut Johannes Seppälä. Joensuu. Brown, Howard Mayer

1980 "Iconography of music". The New Grove Dictionary of Music and Musicians. Vol. 9.

Falcon-Moller, Dorothe

1980 "Musiksymbolik omkring Kristus". 5. nordiske symposium för ikonografiska studier 1976. Kobenhavn.

Haavio, Martti

1932 Leikarit. Vertaileva kansanrunouden tutkimus. Helsinki.

Hammerstein, Reinhold

1962 Die Musik der Engel. Untersuchungen zur Musikanschauung des Mittelalters. München.

1974 Diabolus in Musica. Studien zur Ikonographien der Musik im Mittelalte. Bern und Munchen.

Kunstle, Karl

1979 (1928) "Symbolik und Ikonographie der christlichen künst. Ur Methodologie der christlichen Ikonographie". Ikonographie und Ikonologie. Köln.

Leisiö, Timo

1983 Suomen ja Karjalan vanhakantaiset torvi- ja pillisoittimet. I Nimistö, rakenteet ja historia. Tampere.

Ling, Jan

1983 Europas musikhistoria -1730. Uppsala.

Mahling, Christoph-Hellmut

1976 "Der Dudelsack in westeuropäische Plastik und Malerei". Studia Instrumentorum Musicae Popularis IV. Uddevalla.

Nervander, Emil 1900 "En finsk säckpipblåsare p 1400-talet". Finskt Museum VII. Helsingfors.

Riska, Tove 1959 "Taivassalon kirkko". Suomen kirkot 1. Helsinki.

Suomen historia 2.

1985 Keskiaika ja uuden ajan alku. Espoo.

Wennervirta, L.

1930 "Goottilaista monumentaalimaalausta Länsi-Suomen ja Ahvenanmaan Helsinki. kirkoissa". Suomen Muinaismuistoyhdistyksen Aikakirja XXXVIII:1.

1937 Suomen keskiaikainen kirkkomaalaus. Porvoo.

\section{Summary}

\section{Musical themes in ecclesiastical wall paintings in Finland}

Irma Vierimaa analyses musical themes depicted in art - especially musicians and instruments and their meaning in Finnish Medieval art. The relationships between art and music have been studied for a long time but as a scientifical discipline musical iconology is rather young, it developed in the beginning of this century especially in Germany among music historians. As one can judge from the name, 
it is question of a field of research which tries to connect both art-historical and music-historical methods and source materials.

Ecclesiastical art in Medieval Finland is part of a quite uniform Catholic culture and the most common motives in art were repeated in similar forms throughout Europe. One function of Catholic art was to make doctrine clear, and pictures had other meanings, as well, for example aesthetical values were not without differences. Religious art in Medieval Finland consists mainly of late medieval frescoes. The painters are usually anonymous, but many stylistic similarities indicate near relationships with the Uppland and Stockholm district in Sweden.

Music meant much more than sound during the Middle Ages. Music and its numeral proportions formed the harmony of the universe and by singing people could unite themselves with the harmony of the spheres. The cry, shout and lament of hell could be called the extreme form of music, because even that sound was said to be an aspiration to sing the glory of Lord, albeit it was a reluctant and failed attempt. Mundane music and especially dance music was considered sinful and, for example, in the 15th century law of Sweden-Finland it was forbidden to give presents to the musicians instead of giving them to the church.

Heavenly music has been depicted in a vault-fresco in Kumlinge church. In the vault two angel-musicians play a large harp and a lute. Although neither the Bible nor other scriptures mention that angels play other instruments than wind instruments, angels playing stringed instruments are common in the art, especially near the Virgin Mary and the throne of God. In the Kumlinge fresco the stringed instruments of the angels can be interpreted as symbols of the quietness and beauty of the sound; as the Bible says, the approach of the Lord is announced first with a strong and frightening sound but close to God the sound becomes quiet and soft. In Kumlinge church the angels which have been painted blowing wind instruments, are near the door, but the angels playing stringed instruments have been painted near the main altar, the most holy place in the church and so near to God.

A mundane musician in a religious painting usually means sin and the sinful life. In Taivassalo church there is a fresco showing a kneeling bagpipe player and a woman holding obviously beer and bread. Although this painting seems to be a depiction of everyday life, it is in fact a symbolic representation of sin and its reward. The sinfulness of the player is indicated by his nose that is like the snout of a swine, his unesteemed instrument and even the red colour of his clothes may be an allusion to sin. Under the musician and the woman is a monster, half human half fish. She represents the rewards of sin, that lead men to the edges of the world, far away from God.

In medieval art a shepherd playing an instrument can often be interpreted as a human being participating the heavenly praise to God. In Hattula church is a fresco depicting the story of Joachim and Anna, the parents of Mary. In the painting there is an angel announcing the birth of the Virgin Mary, Joachim, and a shepherd playing a horn. In the story no mention is made of shepherds playing, instead Joachim is said to praise the Lord. The shepherd's instrument is an attribute of his profession as well, and the most commonly represented are the bagpipe and the horn. 
The musical motifs in Medieval art show how music was thought to play a part in the struggle between good and evil. In Finnish art the most frequently depicted music motif is heavenly music played by angels and saints. Human musicians can often be interpreted as representatives of either good or evil forces, but it is not always possible to classify them.

Because our knowledge of music in Medieval Finland is very slight, it would be interesting to clarify whether it is possible to use paintings as evidence of real instruments. However, as it is obvious that Medieval art was not meant to represent reality, it is not possible to use the paintings as historical evidence without a thorough examination of sources. 